\title{
Canonical Wnt Signaling is Necessary for Object Recognition Memory Consolidation
}

\author{
Ashley M. Fortress, Sarah L. Schram, Jennifer J. Tuscher, and Karyn M. Frick \\ Department of Psychology, University of Wisconsin-Milwaukee, Milwaukee, Wisconsin 53211
}

Wnt signaling has emerged as a potent regulator of hippocampal synaptic function, although no evidence yet supports a critical role for Wnt signaling in hippocampal memory. Here, we sought to determine whether canonical $\beta$-catenin-dependent Wnt signaling is necessary for hippocampal memory consolidation. Immediately after training in a hippocampal-dependent object recognition task, mice received a dorsal hippocampal (DH) infusion of vehicle or the canonical Wnt antagonist Dickkopf-1 (Dkk-1; 50, 100, or 200 ng/hemisphere). Twenty-four hours later, mice receiving vehicle remembered the familiar object explored during training. However, mice receiving Dkk-1 exhibited no memory for the training object, indicating that object recognition memory consolidation is dependent on canonical Wnt signaling. To determine how Dkk-1 affects canonical Wnt signaling, mice were infused with vehicle or $50 \mathrm{ng} / \mathrm{hemisphere}$ Dkk-1 and protein levels of Wnt-related proteins (Dkk-1, GSK3 $\beta$, $\beta$-catenin, TCF1, LEF1, Cyclin D1, c-myc, Wnt7a, Wnt1, and PSD95) were measured in the dorsal hippocampus $5 \mathrm{~min}$ or $4 \mathrm{~h}$ later. Dkk-1 produced a rapid increase in Dkk-1 protein levels and a decrease in phosphorylated GSK3 $\beta$ levels, followed by a decrease in $\beta$-catenin, TCF1, LEF1, Cyclin D1, c-myc, Wnt7a, and PSD95 protein levels $4 \mathrm{~h}$ later. These data suggest that alterations in Wnt/GSK3 $\beta / \beta$-catenin signaling may underlie the memory impairments induced by Dkk-1. In a subsequent experiment, object training alone rapidly increased DH GSK3 $\beta$ phosphorylation and levels of $\beta$-catenin and Cyclin D1. These data suggest that canonical Wnt signaling is regulated by object learning and is necessary for hippocampal memory consolidation.

\section{Introduction}

The Wnt family consists of 19 lipid-modified secreted peptides that regulate neural development and differentiation, axon guidance, dendritic morphogenesis, and synaptogenesis (Ciani and Salinas, 2005). Wnt ligands regulate neuronal structure and function through three pathways: (1) the canonical Wnt/ $\beta$-catenin pathway that mediates gene transcription by regulating activation of GSK3 $\beta$ and $\beta$-catenin, (2) the planar cell polarity (PCP) pathway that controls cell polarity and dendritogenesis through activation of Rho GTPases, and (3) the Wnt/calcium pathway that determines cell fate and movement by activating PKC and CaMKII (Ciani and Salinas, 2005; Salinas and Zou, 2008; Inestrosa and Arenas, 2010; Park and Shen, 2012). In the canonical pathway, Wnt ligands bind to the Frizzled receptor and LRP5/6 coreceptor to activate Dishevelled (Wharton, 2003), which disassembles a complex containing a constitutively active GSK $3 \beta$ that degrades $\beta$-catenin (Ciani and Salinas, 2005). GSK3 $\beta$ is inactivated by phosphorylation on Serine 9 , thereby preventing phosphorylation and degradation of $\beta$-catenin (SalcedoTello et al., 2011). Unphosphorylated $\beta$-catenin acts as a cofactor for TCF/LEF transcription factors, downstream targets of which include the cell-cycle regulatory genes Cyclin D1 and c-myc (Zhang et al.,

Received Feb. 12, 2013; revised June 21, 2013; accepted June 21, 2013.

Author contributions: A.M.F. and K.M.F. designed research; A.M.F., S.L.S., and J.J.T. performed research; A.M.F. and K.M.F. analyzed data; A.M.F. and K.M.F. wrote the paper.

This work was supported by the University of Wisconsin-Milwaukee and by an Ellison Medical Foundation/ American Federation for Aging Research Postdoctoral Fellowship in Aging to A.M.F.

Correspondence should be addressed to Karyn M. Frick, PhD, Department of Psychology, University of WisconsinMilwaukee, 2441 E. Hartford Ave., Milwaukee, WI 53211. E-mail: frickk@uwm.edu.

DOI:10.1523/JNEUROSCI.0659-13.2013

Copyright $\odot 2013$ the authors $\quad 0270-6474 / 13 / 3312619-08 \$ 15.00 / 0$
2011) and genes important for synaptic plasticity and memory (Arrázola et al., 2009).

Canonical Wnt signaling regulates hippocampal development (Ciani and Salinas, 2005) and synaptogenesis (Hall et al., 2000), and recent studies reveal an important role for Wnt signaling in hippocampal morphology and synaptic plasticity. Wnt3a is released from hippocampal neurons in an activity-dependent manner and regulates hippocampal neurogenesis and long-term potentiation via canonical Wnt signaling (Lie et al., 2005; Chen et al., 2006). Hippocampal Wnt7a/b levels are regulated by synaptic activity and Wnt7a modulates CA3 synaptogenesis and synaptic transmission (Ahmad-Annuar et al., 2006; Cerpa et al., 2008), suggesting an essential role for canonical Wnt signaling in presynaptic hippocampal function. Wnt signaling also regulates postsynaptic function through noncanonical pathways; Wnt5a promotes clustering of PSD95 and glutamatergic transmission through the Wnt/JNK pathway (Farías et al., 2009) and modulates synaptic differentiation through the Wnt/calcium pathway (Varela-Nallar et al., 2010). Therefore, it is important to differentiate between the effects of canonical and noncanonical Wnt pathways on hippocampal function.

Given its importance to hippocampal plasticity, Wnt signaling likely regulates hippocampal learning and memory. However, only one study has examined the involvement of Wnts in hippocampal learning. That study found that spatial learning increased levels of Wnt7a/b and Wnt5a, but not Wnt3, in rat hippocampus (Tabatadze et al., 2012). However, it was not determined whether this increase was necessary for rats to learn the task. The dependence of learning on Wnt signaling was suggested by another study demonstrating that pretraining infusion of the canonical Wnt antagonist Dickkopf-1 (Dkk-1) into the basolat- 
eral amygdala blocks fear learning (Maguschak and Ressler, 2011). Nevertheless, evidence demonstrating that Wnt signaling is necessary for hippocampal memory is entirely lacking.

Here, we investigated whether canonical Wnt signaling is necessary for hippocampal memory consolidation and measured the extent to which learning alters canonical Wnt signaling. Our findings suggest that hippocampal object recognition memory consolidation is dependent on rapid alterations in canonical Wnt signaling.

\section{Materials and Methods}

Subjects. Male C57BL/6 mice, $8-10$ weeks of age, were obtained from Taconic. Mice were singly housed and maintained on a $12 \mathrm{~h} \mathrm{light/dark}$ cycle (lights on at 07:00) with ad libitum access to food and water. All procedures followed the National Institutes of Health Guide for the Care and Use of Laboratory Animals and were approved by the University of Wisconsin-Milwaukee Animal Care and Use Committee.

Surgery. Mice receiving DH infusions were implanted bilaterally with stainless steel guide cannulae aimed at the DH as described previously (Zhao et al., 2012; Fortress et al., 2013). Using a Kopf stereotaxic apparatus, bilateral guide cannulae (C232GC, 22 gauge; Plastics One) were implanted to target the $\mathrm{DH}(-1.7 \mathrm{~mm} \mathrm{AP}, \pm 1.5 \mathrm{~mm} \mathrm{ML},-2.3 \mathrm{~mm} \mathrm{DV}$, injection site) and were fitted with dummy cannulae (C232DC) to maintain patency of the guide cannulae. Cannulae were attached to the skull surface with dental cement that served to close the wound. Mice were allowed to recover for $7 \mathrm{~d}$ before behavioral testing.

Drugs and infusions. The nonspecific canonical Wnt inhibitor Dkk-1 is an endogenous member of the structurally related Dkk family of proteins that prevents the formation of the Wnt/Frizzled/LRP5/6 complex (Diep et al., 2004; Ciani and Salinas, 2005). This compound was used here to block canonical Wnt signaling. Dkk-1 (R\&D Systems) was dissolved in physiological saline to concentrations of 100,200 , and $400 \mathrm{ng} / \mu \mathrm{l}$. The vehicle was physiological saline. Infusions were delivered bilaterally at a rate of $0.5 \mu \mathrm{l} / \mathrm{min}$ for $1 \mathrm{~min}$ as described previously (Zhao et al., 2012; Fortress et al., 2013), resulting in doses of 50, 100, and $200 \mathrm{ng} / \mathrm{hemi}-$ sphere. Mice were gently restrained and dummy cannulae were replaced with injection cannulae (C232I; 26 gauge, extending $0.8 \mathrm{~mm}$ beyond the $1.5 \mathrm{~mm}$ guide) attached to PE50 tubing connected to a $5 \mu$ l Hamilton syringe. The infuser then remained in place for $1 \mathrm{~min}$ to prevent diffusion back up the cannula track. To pinpoint the effects of Dkk-1 object recognition memory consolidation, infusions were administered immediately after novel object recognition training.

Novel object recognition. Novel object recognition was conducted as described previously (Zhao et al., 2012; Fortress et al., 2013). Mice were each handled $1 \mathrm{~min} / \mathrm{d}$ for $3 \mathrm{~d}$ and then habituated to the apparatus by allowing them to freely explore the empty white testing chamber $(60 \mathrm{~cm} \mathrm{~W} \times 60 \mathrm{~cm} \mathrm{~L} \times 47 \mathrm{~cm} \mathrm{H})$ for $5 \mathrm{~min} / \mathrm{d}$ for $2 \mathrm{~d}$. During handling and habituation, a Lego was placed in the home cage to habituate mice to objects. Twenty-four hours after the second habituation session, mice were rehabituated to the chamber for $2 \mathrm{~min}$ before being presented with two identical objects. Mice were allowed to freely investigate both objects until they accumulated a total of $30 \mathrm{~s}$ of exploration. Time spent with each object was recorded using ANYmaze tracking software (Stoelting).

One set of mice received DH infusion of vehicle or Dkk-1 after training to determine whether Dkk-1 influences novel object recognition memory consolidation. Immediately after novel object recognition training, mice were bilaterally infused with saline $(n=7)$ or Dkk-1 in doses of 50 $(n=8), 100(n=7)$, or $200 \mathrm{ng}(n=7)$ per DH and then returned to their home cages. Posttraining infusions allowed us to specifically pinpoint effects of Dkk-1 to the memory consolidation phase of memory formation (Frick et al., 2010). Mice were returned to the chamber $24 \mathrm{~h}$ later and presented with an object identical to that explored during training (familiar object) and a new object (novel object). Novel object location was counterbalanced across mice. Because mice are inherently drawn to novelty, a preference for the novel object (more time spent exploring the novel object than chance, $15 \mathrm{~s}$ ) indicates intact memory for the familiar object (Gresack and Frick, 2003). Fixing total exploration time rather than trial duration minimizes confounding influences of group differences in activity (Gresack and Frick, 2003).

A second set of mice was killed $5 \min (n=9), 30 \min (n=8)$, or $4 \mathrm{~h}(n=$ 9) after training to examine learning-induced changes in canonical Wnt signaling. These trained mice were compared with home cage controls $(n=$ 8 ) and yoked context-only controls $(n=16)$ that received the habituation and training described above, but were not presented with objects while in the testing chamber. These mice remained in the testing chamber for the same mean duration as the trained mice $(\sim 8 \mathrm{~min})$. Home cage controls remained in their home cages for the duration of the study.

Western blotting. To examine the effects of Dkk-1 on Wnt signaling, mice were infused with vehicle or Dkk-1 and the DH dissected bilaterally. Because analyses revealed that $50 \mathrm{ng} /$ hemisphere was the lowest behaviorally effective dose of Dkk-1, all biochemical measurements were conducted using this dose. To determine the effects of $50 \mathrm{ng}$ of Dkk-1 on immediate and longerterm Wnt signaling, DH tissues were dissected $5 \mathrm{~min}$ or $4 \mathrm{~h}$ after infusion of saline or $50 \mathrm{ng} /$ hemisphere of Dkk-1. To examine alterations in Wnt signaling after object learning, mice were killed $5 \mathrm{~min}, 30 \mathrm{~min}$, or $4 \mathrm{~h}$ after the completion of training. For the context-only group, mice were killed at the same time points as trained animals: $5 \mathrm{~min}(n=5), 30 \mathrm{~min}(n=6)$, or $4 \mathrm{~h}$ $(n=5)$. Home cage controls $(n=8)$ were killed at the same point in the light/dark cycle as the other mice. The $5 \mathrm{~min}$ and $4 \mathrm{~h}$ time points were assayed to match the Dkk-1 experiment and a 30 min time point was added based on songbird data showing rapid experience-induced changes in the brain within 30 min (Remage-Healey et al., 2008). In the figures, representative Western images from the context-only group are shown on the Western blot image, because this group was not statistically different from home cage controls (see below).

For all experiments, tissues were immediately frozen on dry ice after dissection and stored at $-80^{\circ} \mathrm{C}$. Western blotting was conducted as described previously (Zhao et al., 2012; Fortress et al., 2013). Briefly, samples were resuspended 1:25 w/v in lysis buffer, homogenized with a probe sonicator, electrophoresed on Tris-HCl gels, and transferred to PDVF membranes using a TransBlot Turbo system (Bio-Rad). Blots were blocked and incubated overnight at $4^{\circ} \mathrm{C}$ with the following primary antibodies: anti-Dkk-1 (1:500; Santa Cruz Biotechnology), anti-phospho-GSK3 $\beta$ (Ser-9; 1:1000), antiphospho- $\beta$-catenin (Tyr-654; 1:1000), anti-phospho- $\beta$-catenin (Ser33/37/ Thr41; $1: 1000)$, anti- $\beta$-catenin (1:1000), anti-LEF1 (1:1000), anti-TCF1 (1: $1000)$, anti-Cyclin D1 (1:1000), anti-c-myc (1:1000), and anti-PSD95 (1:1000) (all from Cell Signaling Technology), and Wnt1 (1:50) or Wnt7a (1:1000) (both from Abcam). Wnt1 was examined in addition to Wnt7a because fear learning in rats decreases Wntl expression in the amygdala (Maguschak and Ressler, 2011). Blots were then incubated with secondary antibodies conjugated to horseradish peroxidase (Cell Signaling Technology) and developed using West Dura chemiluminescent substrate (Pierce). Next, blots were stripped and reprobed with anti- $\beta$-actin (1:5000; Cell Signaling Technology) for protein normalization. Densitometry was conducted using Gel Logic 6000 Pro (Carestream Healthcare) and ChemiDoc MP (BioRad) imaging systems. Data are expressed as the percentage of immunoreactivity relative to controls.

Statistics. For novel object recognition data, separate one-sample $t$ tests were performed for each group to determine whether the time spent with the novel object differed from chance $(15 \mathrm{~s})$. This analysis was used because time spent with one object necessarily reduces time spent with the other (Gresack and Frick, 2003). Western blotting data were analyzed using one-way ANOVA followed by Fisher's LSD post hoc tests and selected $t$ tests (GraphPad Prism 6 software). For Dkk-1 data, vehicle data from the $5 \mathrm{~min}$ and $4 \mathrm{~h}$ time points did not differ, so these mice were combined into a single vehicle group. For data on learning-induced changes, values for the home-cage and yoked context-only controls did not statistically differ at any time point and were therefore combined into a single control group.

\section{Results}

Canonical Wnt signaling is necessary for object recognition memory consolidation

Mice received bilateral DH infusions of saline or Dkk-1 (50, 100, or $200 \mathrm{ng} /$ hemisphere) immediately after novel object recognition training. Twenty-four hours later, vehicle-infused mice 
A
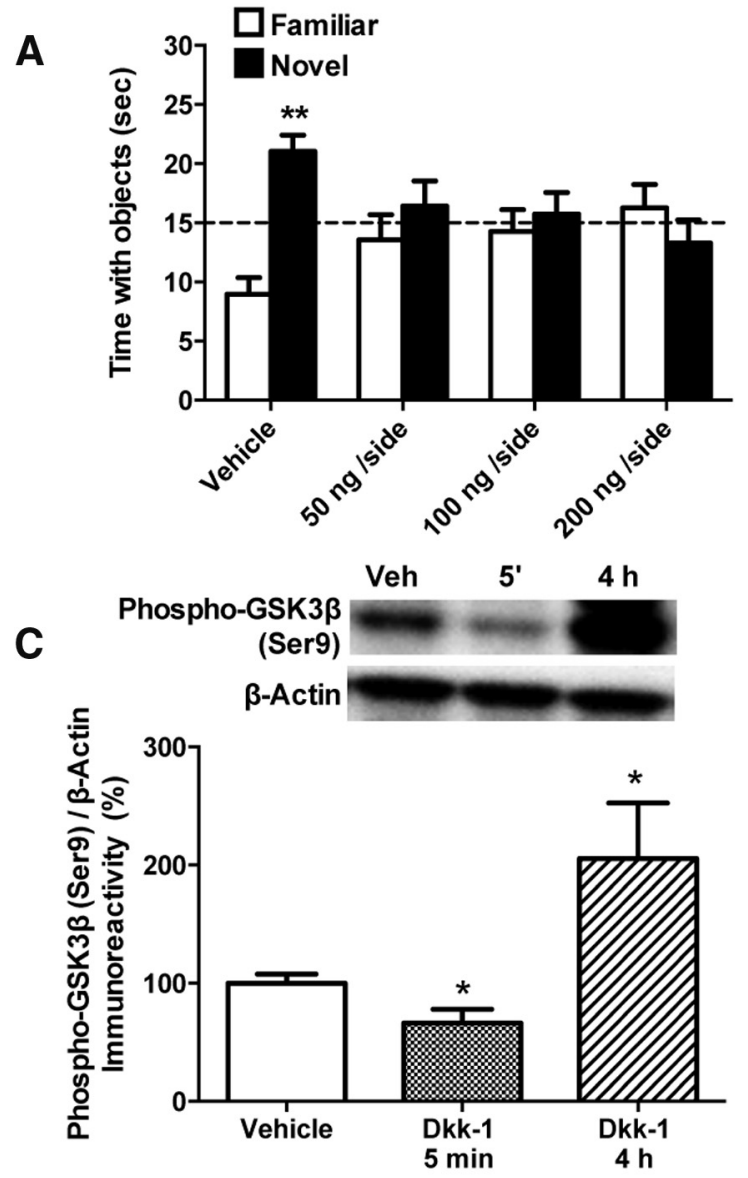

E

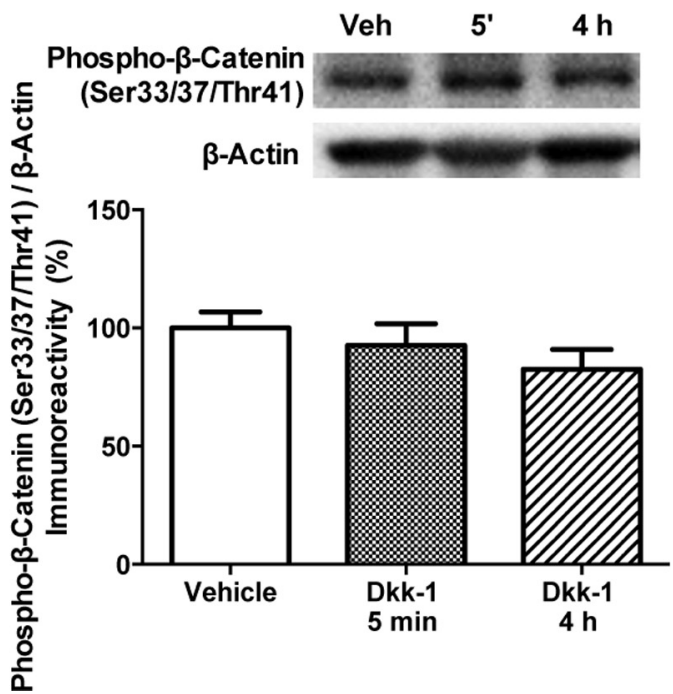

Veh 5'

$4 \mathrm{~h}$

Dkk-1

$\beta$-Actin

B

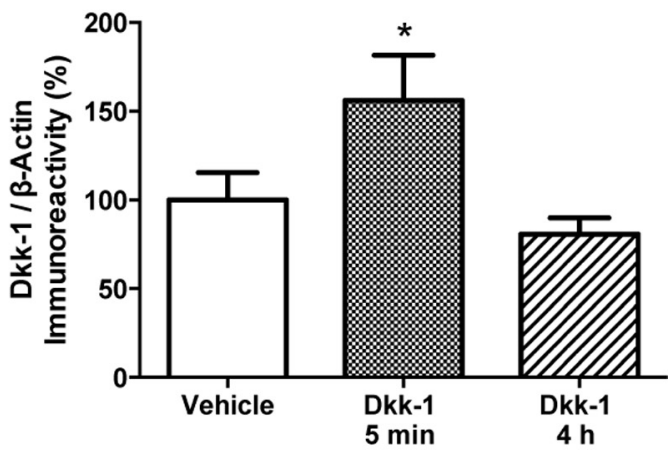

D
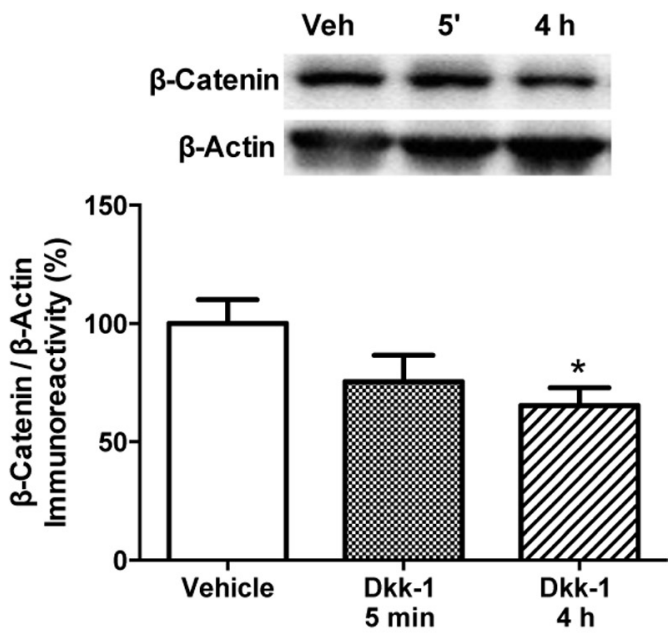

F



Figure 1. Dkk-1 impairs memory consolidation and modulates DH canonical Wnt signaling. A, Bilateral DH infusion of Dkk-1 significantly impaired novel object recognition memory consolidation. Mice were infused immediately after training with vehicle or Dkk-1 (50, 100, or $200 \mathrm{ng} /$ hemisphere). Twenty-four hours later, mice infused with vehicle spent significantly more time than chance (dashed line at $15 \mathrm{~s}$ ) with the novel object ${ }^{* *} p<0.01$ relative to chance), suggesting that they remembered the familiar object. Mice infused with any dose of Dkk-1 did not spend significantly more time than chance with the novel object, suggesting impaired memory consolidation. Each bar represents the mean ( \pm SEM). $\boldsymbol{B}$, Bilateral DH infusion of $50 \mathrm{ng} / \mathrm{hemisphere} \mathrm{Dkk-1}$ significantly increased DH Dkk-1 protein levels 5 min after infusion $\left({ }^{*} p<0.05\right.$ relative to vehicle) and levels returned to baseline $4 \mathrm{~h}$ later. $C$, DH infusion of Dkk-1 significantly decreased phosphorylated GSK3 $\beta$ in the DH at $5 \mathrm{~min}\left({ }^{*} p<0.05\right.$ relative to vehicle), followed by a significant increase at $4 \mathrm{~h}\left({ }^{*} p<0.05\right.$ relative to vehicle and $\left.5 \mathrm{~min}\right) . \boldsymbol{D}, \mathrm{DH}$ infusion of $50 \mathrm{ng} / \mathrm{hemisphere} \mathrm{Dkk-1}$ significantly decreased total $\beta$-catenin levels $4 \mathrm{~h}$ later $\left({ }^{*} p<0.05\right.$ relative to vehicle). Dkk-1 did not affect phosphorylation of $\beta$-catenin on Ser33/37/Thr $41(\boldsymbol{E})$ or Tyr654 (F). All proteins normalized to $\beta$-actin (each bar represents the mean \pm SEM percent change from vehicle). Insets are representative Western blots showing total and phosphorylated protein levels. 
spent significantly more time with the novel object than chance $\left(t_{(6)}=4.33, p=\right.$ 0.005; Fig. 1A), suggesting that they remembered the familiar object. In contrast, mice receiving Dkk-1 spent no more time than chance with the novel object (Fig. 1A), demonstrating that inhibition of canonical Wnt signaling in the DH impairs novel object recognition memory consolidation.

\section{Dkk-1 increases Dkk-1 protein levels}

To confirm that Dkk-1 infusion increased $\mathrm{DH}$ levels of Dkk-1 protein, mice were bilaterally infused with the lowest behaviorally effective dose of Dkk-1 (50 $\mathrm{ng} /$ hemisphere) and the $\mathrm{DH}$ was dissected bilaterally $5 \mathrm{~min}$ and $4 \mathrm{~h}$ later. Dkk-1 infusion significantly increased levels of Dkk-1 protein $\left(F_{(2,17)}=4.7\right.$, $p=0.02$; Fig. $1 B$ ) such that Dkk-1 was significantly increased 5 min after infusion ( $p=0.05$ relative to vehicle) and returned to baseline $4 \mathrm{~h}$ after infusion. These data indicate that Dkk-1 levels in the $\mathrm{DH}$ were rapidly, but transiently, increased after Dkk-1 infusion.

\section{GSK3 $\beta$ and $\beta$-catenin are altered by Dkk-1}

We next measured the effects of Dkk-1 on GSK $3 \beta$ and $\beta$-catenin in the DH. Dkk-1 significantly altered phosphoGSK3 $\beta$ levels $\left(F_{(2,18)}=5.47, p=0.01\right.$; Fig. $1 C)$ such that levels were significantly decreased 5 min after infusion $\left(t_{(11)}=2.33, p=0.04\right)$ and increased $4 \mathrm{~h}$ after infusion $(p<0.03)$. Dkk-1 did not significantly affect total GSK3 $\beta$ levels (data not shown). These data suggest a rapid dephosphorylation of GSK3 $\beta$, followed by a longer-term hyperphosphorylation. Because phosphorylation inactivates GSK $3 \beta$, which then prevents phosphorylation of $\beta$-catenin (Salcedo-Tello et al., 2011), we next measured phospho- and total $\beta$-catenin levels. Total $\beta$-catenin was significantly affected by Dkk-1 $\left(F_{(2,17)}=3.64, p=0.05\right.$; Fig. $\left.1 D\right)$ due to a significant decrease relative to vehicle $4 \mathrm{~h}$ after infusion $(p=0.01)$. We next examined $\beta$-catenin phosphorylation at the GSK3-sensitive sites Ser33/Ser37/Thr41 (Liu et al., 2002) and found no effect of Dkk-1 (Fig. 1E). We then measured $\beta$-catenin phosphorylation on Tyr654, because phosphorylation at this site reduces training-induced interactions between $\beta$-catenin and cadherin in the amygdala (Maguschak and Ressler, 2008). However, Dkk-1 did not affect phospho$\beta$-catenin at this site either (Fig. $1 F$ ). These data suggest that Dkk-1 reduces total $\beta$-catenin without affecting phospho- $\beta$ catenin, at least at the time points and phosphorylation sites measured.

\section{Downstream targets of $\boldsymbol{\beta}$-catenin are decreased by Dkk-1}

Because unphosphorylated $\beta$-catenin is a cofactor for TCF/LEF transcription factors (Chen and Bodles, 2007), the Dkk-1induced reduction in total $\beta$-catenin should decrease the expression of TCF/LEF-induced genes such as Cyclin D1 and c-myc. We first examined effects of Dkk-1 on the transcription factors TCF1
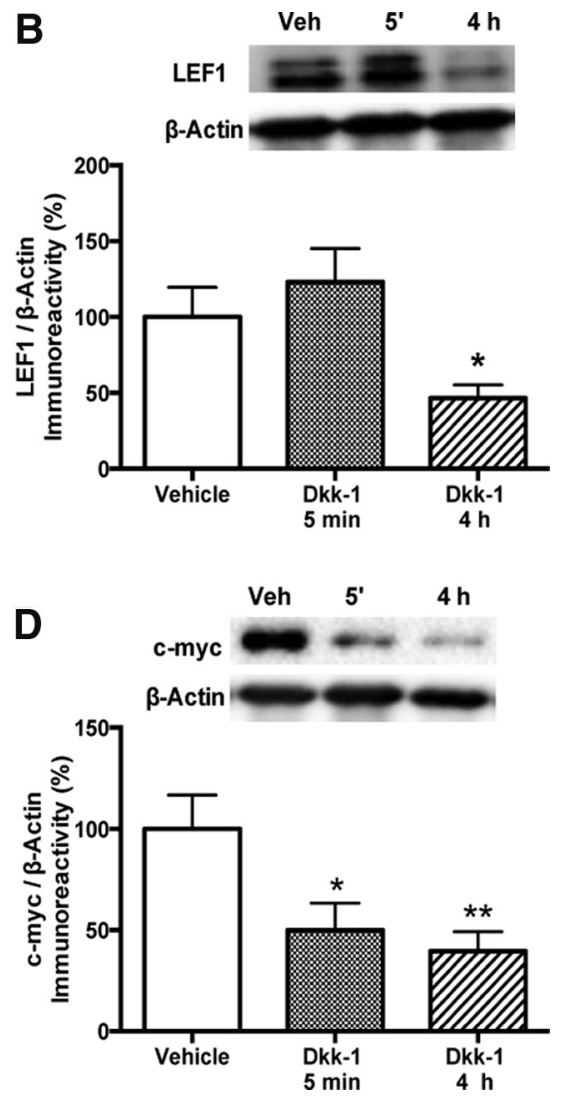

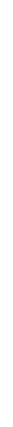

Figure 2. Dkk-1 in the DH downregulates downstream $\beta$-catenin targets. Bilateral DH infusion of $50 \mathrm{ng} / \mathrm{hemisphere} \mathrm{Dkk-1}$ ignificantly decreased protein levels of the transcription factors TCF1 $(\boldsymbol{A})$ and LEF1 $(\boldsymbol{B}) 4 \mathrm{~h}$ after infusion ${ }^{*} p<0.05$ relative to relative to vehicle and $5 \mathrm{~min})$. $\boldsymbol{D}, \mathrm{c}-\mathrm{myc}$ was significantly decreased both $5 \mathrm{~min}\left({ }^{*} p<0.05\right)$ and $4 \mathrm{~h}$ after infusion $\left({ }^{* *} p<0.01\right)$. Each bar represents the mean \pm SEM percent change from vehicle. Insets show representative Western blots.

and LEF1. Dkk-1 significantly affected TCF1 protein levels in the $\mathrm{DH}\left(F_{(2,19)}=3.91, p=0.04\right.$; Fig. $\left.2 A\right)$ such that levels were significantly reduced $4 \mathrm{~h}$ after infusion relative to the vehicle $\left(t_{(12)}=\right.$ 2.94, $p=0.01)$ and $5 \min (p<0.05)$ groups. Similarly, Dkk-1 infusion significantly reduced LEF1 protein levels $\left(F_{(2,20)}=5.13\right.$, $p=0.02$; Fig. $2 B)$ due to a significant decrease at $4 \mathrm{~h}$ compared with the vehicle and 5 min groups $(p<0.05)$. To investigate whether the downregulation of $\beta$-catenin at $4 \mathrm{~h}$ affected downstream TCF/LEF targets, we assayed Cyclin D1 and c-myc and found that Cyclin D1 protein levels were significantly affected by Dkk-1 infusion $\left(F_{(2,19)}=3.7, p=0.04\right.$; Fig. $\left.2 C\right)$ due to a decrease of Cyclin D1 $4 \mathrm{~h}$ after infusion relative to the vehicle $\left(t_{(12)}=2.57\right.$, $p=0.02)$ and 5 min $(p<0.05)$ groups. Furthermore, Dkk-1 caused a substantial reduction in $\mathrm{c}$-myc protein expression $\left(F_{(2,18)}=5.84, p=0.01\right.$; Fig. $\left.2 D\right)$ due to significant decreases both $5 \mathrm{~min}(p<0.05)$ and $4 \mathrm{~h}(p<0.01)$ after infusion. This evidence supports the idea that Dkk-1 affects downstream targets of the canonical $\mathrm{Wnt} / \beta$-catenin signaling pathway.

\section{Dkk-1 decreases levels of Wnt7a and PSD95}

We next investigated the effects of Dkk-1 on protein levels in the $\mathrm{DH}$ of the Wnt ligands Wntl and Wnt7a and the postsynaptic density protein PSD95. Although none of these originates from an identified TCF/LEF gene, we were interested in the effects of Dkk-1 on these proteins because they are associated with hippocampal learning and plasticity. For example, Wnt1 is significantly decreased in the amygdala after fear learning (Maguschak and Ressler, 2011) and Wnt7a/b is significantly increased in the 
hippocampus after spatial learning (Tabatadze et al., 2012). Furthermore, in vitro studies report that Wnt7a activates the canonical $\mathrm{Wnt} / \beta$-catenin pathway, promotes synaptic vesicle recycling, and increases neurotransmitter release in cultured hippocampal neurons (Cerpa et al., 2008), whereas Dkk-1 attenuates the ability of Wnt7a to activate canonical Wnt signaling (Spinsanti et al., 2008). Therefore, we hypothesized that Dkk-1 may regulate $\mathrm{DH}$ levels of Wnt1 and Wnt7a. Although Dkk-1 did not significantly affect Wnt1 protein levels (Fig. 3A), Wnt7a protein levels were significantly reduced $\left(F_{(2,20)}=3.9, p=0.04\right.$; Fig. $\left.3 B\right)$ relative to vehicle $4 \mathrm{~h}$ after infusion $(p<0.05)$. We next examined the postsynaptic protein PSD95 because environmental enrichment increases both Wnt7a and PSD95 (Gogolla et al., 2009) and Dkk-1 decreases hippocampal PSD95 levels in vitro (Purro et al., 2012). Dkk-1 significantly affected PSD95 protein levels $\left(F_{(2,20)}=\right.$ $8.78, p=0.0018$; Fig. $3 C)$, an effect driven by a significant reduction relative to vehicle $4 \mathrm{~h}$ after infusion $(p<0.001)$.

Canonical Wnt proteins in the $\mathrm{DH}$ are altered by object training

Because infusion of an endogenous inhibitor of canonical Wnt signaling blocked novel object recognition memory consolidation and altered levels of several key canonical Wnt signaling proteins, we questioned whether object training itself might activate canonical Wnt signaling. Therefore, we trained a new set of mice with two identical objects and then collected the DH bilaterally $5 \mathrm{~min}, 30 \mathrm{~min}$, or $4 \mathrm{~h}$ later. Mice killed $5 \mathrm{~min}, 30 \mathrm{~min}$, or $4 \mathrm{~h}$ after training did not differ in the time to accumulate $30 \mathrm{~s}$ of exploration ( $5 \mathrm{~min}: 468.6 \pm$ $103.8 \mathrm{~s} ; 30 \mathrm{~min}: 395.9 \pm 66.14 \mathrm{~s} ; 4 \mathrm{~h}: 566.0 \pm 74.08 \mathrm{~s})$. All proteins examined in the Dkk-1 study were measured here as well.

Training had no significant effect on DH levels of Dkk-1, total GSK3 $\beta$, phospho- $\beta$-catenin, TCF, LEF, c-myc, or Wnt1 (data not shown). However, object training affected several other proteins. Levels of phospho-GSK3 $\beta$ were significantly altered by training $\left(F_{(3,43)}=2.91, p=0.05\right.$; Fig. $\left.4 A\right)$, although this effect was driven largely by a significant increase in phospho-GSK3 $\beta 30 \mathrm{~min}$ after training relative to controls $(p<0.05)$. Total unphosphorylated $\beta$-catenin levels were rapidly and persistently increased by training $\left(F_{(3,40)}=4.63, p=0.01\right.$; Fig. $\left.4 B\right)$, with substantial increases relative to controls observed $5 \mathrm{~min}(p<0.01)$ and $4 \mathrm{~h}$ $(p<0.05)$ after training and a smaller increase evident $30 \mathrm{~min}$ after training $\left(t_{(25)}=2.51, p=0.02\right)$. Downstream from $\beta$-catenin, object training significantly increased Cyclin D1 levels $\left(F_{(3,45)}=2.9, p=0.04\right.$; Fig. $\left.4 C\right)$, which peaked at $5 \mathrm{~min}(p<$ $0.05)$ but were also evident at $30 \mathrm{~min}\left(t_{(28)}=2.21, p=0.04\right)$ and $4 \mathrm{~h}\left(t_{(30)}=2.1, p=0.05\right)$, suggesting learning-induced activation of at least one aspect of TCF/LEF signaling. Although the main effect of group was not significant for Wnt7a and PSD95, learning facilitated a subtle increase relative to controls in Wnt7a 5 min after training $\left(t_{(28)}=2.76, p=0.01\right.$; Fig. $\left.4 D\right)$ and in PSD95 $4 \mathrm{~h}$ after training $\left(t_{(25)}=2.1, p=0.04\right.$; Fig. $\left.4 E\right)$. These data suggest that object training can influence several key components of $\mathrm{Wnt} / \beta$-catenin signaling in the $\mathrm{DH}$, most notably increasing total $\beta$-catenin and Cyclin-D1 levels.

\section{Discussion}

Accumulating evidence suggests that Wnt proteins regulate hippocampal synaptic plasticity (Chen et al., 2006; Cerpa et al., 2008; Salinas and Zou, 2008; Gogolla et al., 2009; Cerpa et al., 2011) and are increased by hippocampal learning (Tabatadze et al., 2012). The present findings that canonical Wnt proteins are increased in the $\mathrm{DH}$ by object learning support an important role for Wnt signaling in hippocampal memory. However, the dependence of hippocampal

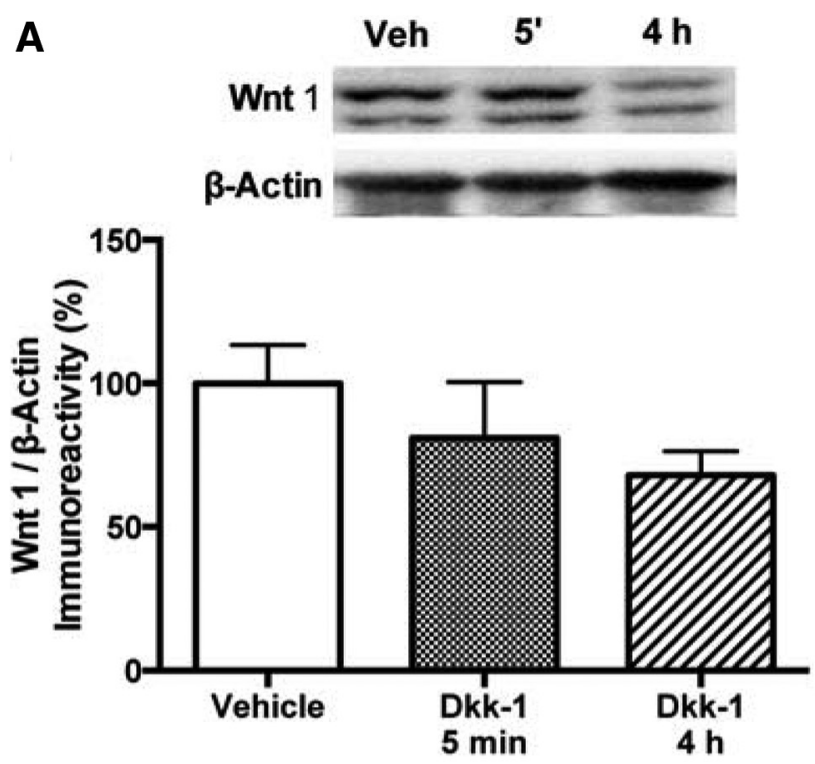

B Veh $\quad 5$ ' $4 \mathrm{~h}$
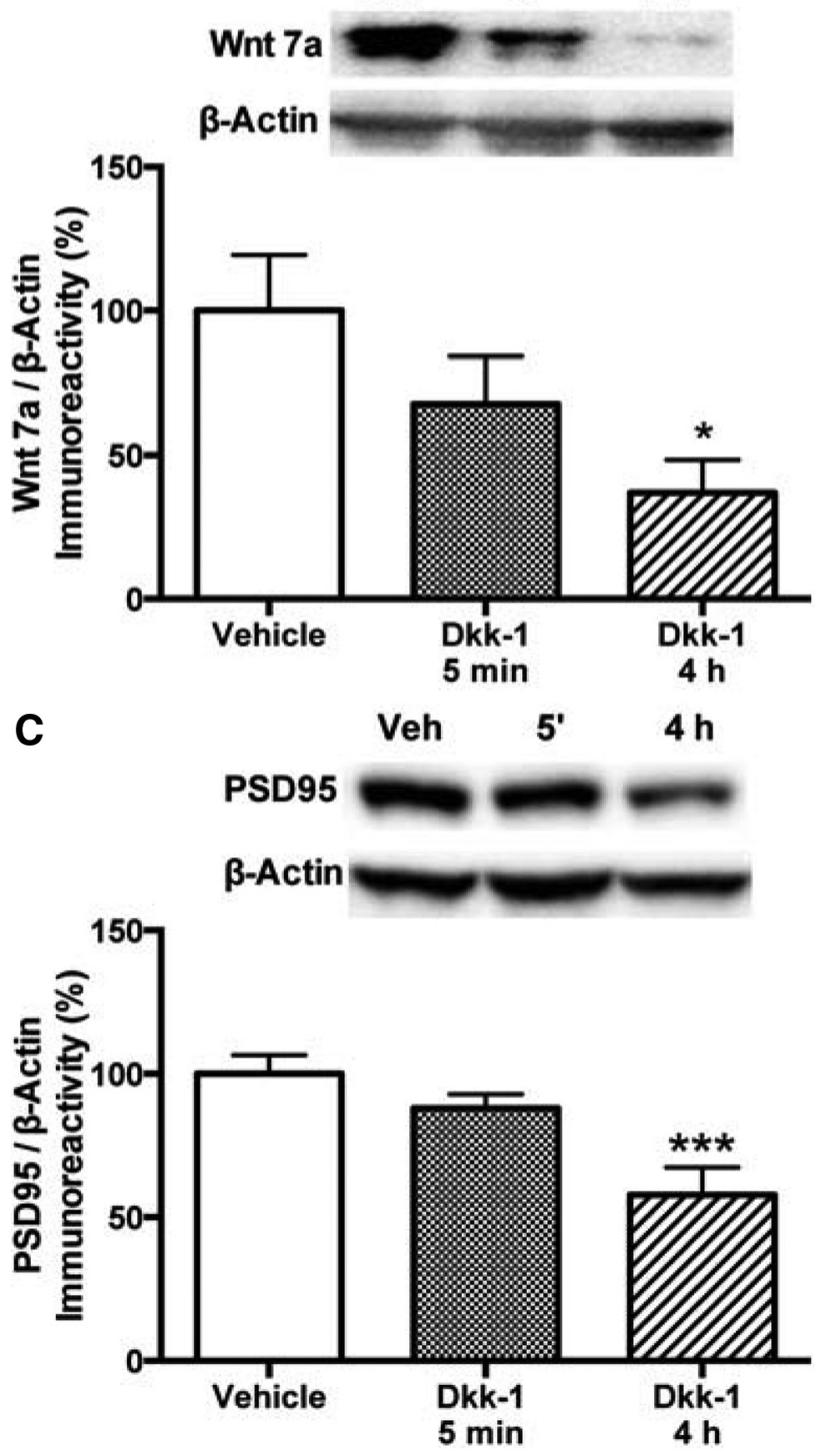

Figure 3. Dkk-1 decreases Wnt7a and PSD95 protein levels in the DH. $A$, Bilateral DH infusion of $50 \mathrm{ng} /$ hemisphere Dkk-1 did not significantly affect Wnt1 protein levels. $\boldsymbol{B}$, Dkk-1 significantly decreased Wnt7a protein $4 \mathrm{~h}$ after infusion (Figure legend continues.) 

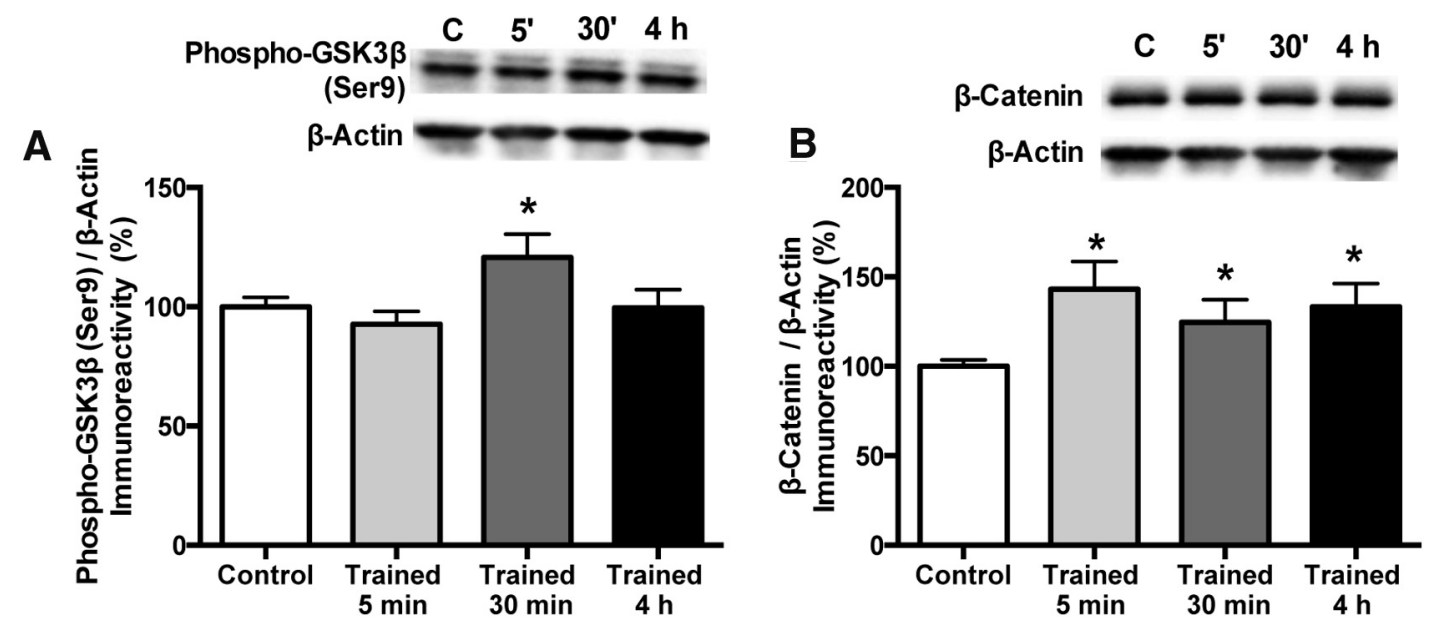

C $\quad 5^{\prime} \quad 30^{\prime} \quad 4 \mathrm{~h}$
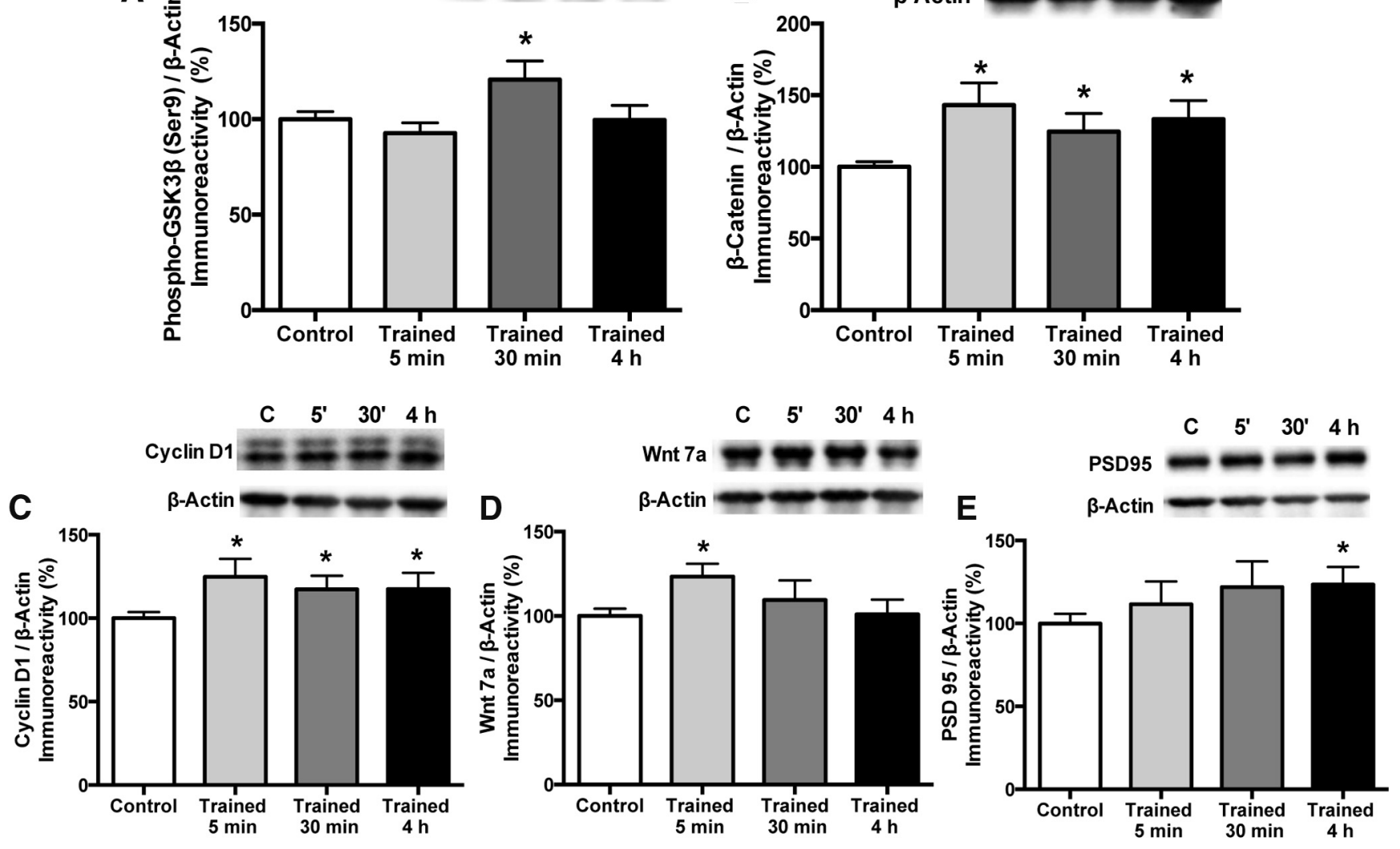

Figure 4. Learning-induced changes in canonical Wnt signaling. $A$, Object training significantly increased phospho-GSK3 $\beta$ levels 30 min after training $\left({ }^{*} p<0.05\right.$ relative to controls). Protein levels of total $\beta$-catenin $(\boldsymbol{B})$ and Cyclin D1 (C) were significantly increased $5 \mathrm{~min}, 30 \mathrm{~min}$, and $4 \mathrm{~h}$ after training $\left({ }^{*} p<0.05\right.$ relative to controls). After training, Wnt7a protein levels (D) were significantly increased at 5 min and PSD95 levels $(\boldsymbol{E})$ were significantly increased at $4 \mathrm{~h}\left({ }^{*} p<0.05\right.$ relative to controls). Protein levels normalized to $\beta$-actin. Each bar represents the mean \pm SEM percent change from vehicle. Insets show representative Western blots.

learning and memory on Wnt signaling has thus far been unclear. The present study provides the first evidence that canonical Wnt signaling is necessary for hippocampal memory consolidation. We used the canonical Wnt inhibitor Dkk-1 to block $\beta$-catenindependent Wnt signaling. Dkk-1 inhibits Wnt/ $\beta$-catenin signaling by binding to LRP5/6 and preventing Wnt interactions with Frizzled receptors. Endogenous Dkk-1 is increased by excitotoxicity, ischemia, and epilepsy and is increased in postmortem Alzheimer's brains, where it is associated with plaques and neurofibrillary tangles (Caraci et al., 2008; Purro et al., 2012). These findings linking Dkk-1 to neural dysfunction are consistent with our results showing that intrahippocampal infusion of Dkk-1 impairs hippocampal memory. Our data also fit well with a report showing that basolateral amygdala infusion of Dkk-1 before fear learning impaired long-term fear memory consolidation (Maguschak and Ressler, 2011). Therefore, the fact that Dkk-1 impairs two distinct types of memories when infused into multiple brain regions suggests a more general role for canonical Wnt signaling in mediating memory consolidation.

(Figure legend continued.) $\left({ }^{*} p<0.05\right.$ relative to vehicle). C, PSD95 protein levels were significantly reduced in the $\mathrm{DH} 4 \mathrm{~h}$ after DH infusion of Dkk-1 ${ }^{* * *} p<0.001$ relative to vehicle). Protein levels normalized to $\beta$-actin. Each bar represents the mean \pm SEM percent change from vehicle. Insets show representative Western blots.
The memory-impairing effects of Dkk-1 likely stem from alterations in Wnt/ $\beta$-catenin signaling. Normally, Wnt ligands binding to the Frizzled-LRP5/6 receptor complex increase phosphorylation of GSK $3 \beta$, which prevents $\beta$-catenin from being phosphorylated and degraded (thereby increasing $\beta$-catenin levels) and allows $\beta$-catenin to increase transcription of downstream gene targets (Ciani and Salinas, 2005). Reduction of Dkk-1 expression by RNA interference in hepatocellular carcinoma cells significantly increases $\beta$-catenin levels and nuclear translocation of $\beta$-catenin (Qin et al., 2007). We therefore predicted that Dkk-1 would decrease DH GSK3 $\beta$ phosphorylation and total levels of $\beta$-catenin, whereas learning would increase phospho-GSK3 $\beta$ and total $\beta$-catenin. Although learning produced the expected increase in these proteins, Dkk- 1 significantly decreased phospho-GSK $3 \beta$ levels 5 min after infusion, but then surprisingly increased GSK3 $\beta$ phosphorylation $4 \mathrm{~h}$ later. This unexpected Dkk-induced hyperphosphorylation may reflect a compensatory response to the initial $5 \mathrm{~min}$ downregulation of phospho-GSK3 $\beta$. Indeed, suppression of canonical $\mathrm{Wnt} / \beta$ catenin signaling by Dkk-1 produces $\mathrm{Wnt} / \beta$-catenin hyperactivation in mouse embryonic stem cells (Rai et al., 2012). Alternatively, noncanonical Wnt signaling may influence canonical signaling in the absence of Wnt binding, as suggested by reports that amyloid beta $(\mathrm{A} \beta)$ increases GSK3 $\beta$ phosphorylation in rat hippocampus through the JNK/PCP Wnt pathway (Hu et al., 2009). 
Further, Dkk-1 activates noncanonical JNK/PCP Wnt signaling in primary neuronal cultures and mouse embryonic stem cells, perhaps through the Frizzled receptor (Killick et al., 2012). These results suggest mechanisms through which Dkk-1 may increase GSK3 $\beta$ phosphorylation that should be addressed in future studies.

Phosphorylation of $\beta$-catenin by GSK3 $\beta$ regulates levels of $\beta$-catenin protein. When GSK3 $\beta$ is activated via dephosphorylation, it phosphorylates $\beta$-catenin and marks it for degradation (Ciani and Salinas, 2005). Therefore, we expected Dkk-1 to increase phospho- $\beta$-catenin and decrease total $\beta$-catenin protein levels and for learning to have the opposite effects. As predicted, Dkk- 1 decreased total $\beta$-catenin protein levels $4 \mathrm{~h}$ after infusion, whereas learning produced a sustained increase in $\beta$-catenin levels. Interestingly, however, neither treatment affected phospho$\beta$-catenin at either the GSK3 $\beta$-sensitive Ser33/37/Thr41 sites or at Tyr654. Although our antibodies were robust enough to measure phospho- $\beta$-catenin levels, a treatment-induced change in phosphorylation may be difficult to capture without inhibition of dephosphorylation or ubiquitination given that $\beta$-catenin is rapidly ubiquitinated and targeted for degradation by the $26 \mathrm{~S}$ proteasomal system once phosphorylated (Sadot et al., 2002). Perhaps treatment-induced phosphorylation events are more easily reversed than baseline phosphorylation or newly phosphorylated $\beta$-catenin is preferentially targeted for ubiquitination. Alternatively, treatment-induced changes may have occurred at time points other than those assayed here. Phosphorylation of Tyr654 is associated with decreased affinity of $\beta$-catenin for cadherin, a process associated with dendritic spine remodeling (Murase et al., 2002). In the amygdala, contextual fear conditioning produces dynamic changes in Tyr654 phosphorylation associated with the destabilization and stabilization of $\beta$-catenin and cadherin that leads to memory consolidation (Maguschak and Ressler, 2008). Because we saw no change in Tyr654 phosphorylation after Dkk-1 infusion or learning, these data suggest potentially different $\mathrm{Wnt}$ mechanisms responsible for memory consolidation in the hippocampus and amygdala.

Alterations in total $\beta$-catenin protein levels should influence gene expression and protein translation. Because total $\beta$-catenin protein was decreased by Dkk-1 and increased by learning, we expected that levels of downstream $\beta$-catenin targets would also be decreased by Dkk-1 and increased by learning. We first examined TCF1 and LEF1, both of which are repressively bound to Wnt response elements until displaced by $\beta$-catenin entering the nucleus (Zhang et al., 2011). Both TCF1 and LEF1 were decreased $4 \mathrm{~h}$ after Dkk-1 infusion. Although the mechanism for this decrease is unclear, the net effect of this downregulation could reduce the amount of TCF1 and LEF1 available to interact with $\beta$-catenin, thus preventing the transcription of downstream target genes. This notion is supported by evidence that NARF (nemo-like kinase associated RING finger protein) negatively regulates Wnt signaling by inducing ubiquitination and degradation of TCF/LEF proteins (Yamada et al., 2006). Interestingly, learning had no effect on the levels of TCF1 or LEF1, suggesting that learning may affect how these transcription factors interact with Wnt response elements rather than levels of the transcription factors themselves. We next measured levels of two downstream TCF/LEF targets, Cyclin D1 and c-myc (Shtutman et al., 1999). Cyclin D1 is an important regulator of the cell cycle (Amendola et al., 2009) and c-myc regulates neural precursor activity during development (Wey et al., 2010). Further, c-myc loss is associated with apoptosis (Amendola et al., 2009) and decreased brain size (Wey and Knoepfler, 2010). Given their role in cell proliferation, Wnt-induced alterations in Cyclin D1 and c-myc may influence hippocampal neurogenesis, a critical ele- ment of long-term memory formation (Epp et al., 2013). Recent evidence demonstrates a role for $\mathrm{Wnt} / \beta$-catenin signaling in hippocampal neurogenesis (Zhang et al., 2011); in particular, Wnt7a stimulates hippocampal neural stem cell proliferation by activating $\beta$-catenin/Cyclin D1 signaling (Qu et al., 2013). Dkk-1 decreased both Cyclin D1 and c-myc, although the effect on c-myc was more rapid and robust. Learning did not alter c-myc protein levels, but significantly increased Cyclin D1 in a rapid and persistent manner. It should be noted that the rapidity of these effects are unlikely to reflect $\beta$-catenin-mediated transcription, so these protein alterations at $5 \mathrm{~min}$ are more plausibly due to changes in the rate of translation or degradation. Nevertheless, because hippocampal learning promotes neurogenesis (Epp et al., 2013), the Cyclin D1 and c-myc data suggest that Dkk-1 may impair memory consolidation by inhibiting hippocampal neurogenesis (or promoting apoptosis), whereas learning may promote neurogenesis via Wnt signaling. In support of this notion, deletion of Dkk-1 restores neurogenesis and reverses memory loss in aged mice (Seib et al., 2013). Future studies should address how Wntinduced alterations in neurogenesis affect hippocampal memory.

Finally, we examined effects of Dkk-1 and learning on the Wnt ligands Wnt1 and Wnt7a and on the postsynaptic protein PSD95. $\mathrm{Wnt} 7 \mathrm{a} / \mathrm{b}$ is increased in the hippocampus after spatial learning (Tabatadze et al., 2012) and Wntl is reduced in the amygdala after fear learning (Maguschak and Ressler, 2011). Here, learning increased Wnt7a within 5 min and Dkk-1 reduced Wnt7a levels $4 \mathrm{~h}$ after infusion, consistent with in vitro data showing that Dkk-1 attenuates the ability of Wnt7 a to activate canonical Wnt signaling (Spinsanti et al., 2008). Interestingly, neither treatment affected Wnt1 levels, potentially revealing distinct roles for Wnt7a and Wntl in hippocampal memory consolidation or reflecting differences between Wnt signaling in the hippocampus and amygdala. Within the hippocampus, the effects of Dkk-1 and learning are consistent with the emerging role of Wnt7a in hippocampal synaptogenesis. Wnt7a increases the density and maturity of hippocampal dendritic spines (Gogolla et al., 2009; Ciani et al., 2011) and Frizzled5 receptors mediate the activitydependent synaptogenic effects of Wnt7a by increasing vGlut 1 and PSD95 (Sahores et al., 2010). Therefore, Dkk-1 may prevent interactions between Wnt7a and Frizzled5 that facilitate the synaptogenesis necessary for memory consolidation. Interestingly, $A \beta$ induced Dkk-1 overexpression in vitro significantly increases hippocampal synaptic loss and disassembly, including associated decreases in vGlut1 and PSD95 (Purro et al., 2012). These findings correspond with our in vivo data showing that Dkk-1 decreased PSD95 levels, whereas learning increased PSD95. Because PSD95 is regulated by noncanonical Wnt5a/JNK signaling (Farías et al., 2009), these data suggest that interactions between canonical and noncanonical Wnt signaling may be important to memory consolidation.

In conclusion, the present study provides the first evidence that canonical Wnt signaling is necessary for hippocampal memory consolidation and that learning rapidly activates canonical Wnt signaling in the DH. The findings indicate that Dkk-1 impairs hippocampal-dependent novel object recognition memory by rapidly decreasing $\beta$-catenin, Cyclin D1, c-myc, Wnt7a, and PSD95 protein levels. In addition, our findings suggest that learning may facilitate the Wnt signaling necessary for hippocampal memory consolidation. Our results suggest a vital new role for canonical Wnt signaling in the consolidation of hippocampal memory.

\section{References}

Ahmad-Annuar A, Ciani L, Simeonidis I, Herreros J, Fredj NB, Rosso SB, Hall A, Brickley S, Salinas PC (2006) Signaling across the synapse: a role for 
Wnt and Dishevelled in presynaptic assembly and neurotransmitter release. J Cell Biol 174:127-139. CrossRef Medline

Amendola D, De Salvo M, Marchese R, Verga Falzacappa C, Stigliano A, Carico E, Brunetti E, Moscarini M, Bucci B (2009) Myc downregulation affects cyclin D1/cdk4 activity and induces apoptosis via Smac/ Diablo pathway in an astrocytoma cell line. Cell Prolif 42:94-109. CrossRef Medline

Arrázola MS, Varela-Nallar L, Colombres M, Toledo EM, Cruzat F, Pavez L, Assar R, Aravena A, González M, Montecino M, Maass A, Martínez S, Inestrosa NC (2009) Calcium/calmodulin-dependent protein kinase type IV is a target gene of the Wnt/beta-catenin signaling pathway. J Cell Physiol 221:658-667. CrossRef Medline

Caraci F, Busceti C, Biagioni F, Aronica E, Mastroiacovo F, Cappuccio I, Battaglia G, Bruno V, Caricasole A, Copani A, Nicoletti F (2008) The Wnt antagonist, Dickkopf-1, as a target for the treatment of neurodegenerative disorders. Neurochem Res 33:2401-2406. CrossRef Medline

Cerpa W, Godoy JA, Alfaro I, Farías GG, Metcalfe MJ, Fuentealba R, Bonansco C, Inestrosa NC (2008) Wnt-7a modulates the synaptic vesicle cycle and synaptic transmission in hippocampal neurons. J Biol Chem 283:5918-5927. CrossRef Medline

Cerpa W, Gambrill A, Inestrosa NC, Barria A (2011) Regulation of NMDAreceptor synaptic transmission by Wnt signaling. J Neurosci 31:9466-9471. CrossRef Medline

Chen J, Park CS, Tang SJ (2006) Activity-dependent synaptic Wnt release regulates hippocampal long term potentiation. J Biol Chem 281: 11910-11916. CrossRef Medline

Chen Y, Bodles AM (2007) Amyloid precursor protein modulates betacatenin degradation. J Neuroinflammation 4:29. CrossRef Medline

Ciani L, Salinas PC (2005) WNTs in the vertebrate nervous system: from patterning to neuronal connectivity. Nat Rev Neurosci 6:351-362. CrossRef Medline

Ciani L, Boyle KA, Dickins E, Sahores M, Anane D, Lopes DM, Gibb AJ, Salinas PC (2011) Wnt7a signaling promotes dendritic spine growth and synaptic strength through $\mathrm{Ca}(2)(+) /$ Calmodulin-dependent protein kinase II. Proc Natl Acad Sci U S A 108:10732-10737. CrossRef Medline

Diep DB, Hoen N, Backman M, Machon O, Krauss S (2004) Characterisation of the Wnt antagonists and their response to conditionally activated Wnt signalling in the developing mouse forebrain. Brain Res Dev Brain Res 153:261-270. CrossRef Medline

Epp JR, Chow C, Galea LA (2013) Hippocampus-dependent learning influences hippocampal neurogenesis. Front Neurosci 7:57. CrossRef Medline

Farías GG, Alfaro IE, Cerpa W, Grabowski CP, Godoy JA, Bonansco C, Inestrosa NC (2009) Wnt-5a/JNK signaling promotes the clustering of PSD-95 in hippocampal neurons. J Biol Chem 284:15857-15866. CrossRef Medline

Fortress AM, Fan L, Orr PT, Zhao Z, Frick KM (2013) Estradiol-induced object recognition memory consolidation is dependent on activation of mTOR signaling in dorsal hippocampus. Learn Mem 20:147-155. CrossRef Medline

Frick KM, Fernandez SM, Harburger LL (2010) A new approach to understanding the molecular mechanisms through which estrogens affect cognition. Biochim Biophys Acta 1800:1045-1055. CrossRef Medline

Gogolla N, Galimberti I, Deguchi Y, Caroni P (2009) Wnt signaling mediates experience-related regulation of synapse numbers and mossy fiber connectivities in the adult hippocampus. Neuron 62:510-525. CrossRef Medline

Gresack JE, Frick KM (2003) Male mice exhibit better spatial working and reference memory than females in a water-escape radial arm maze task. Brain Res 982:98-107. CrossRef Medline

Hall AC, Lucas FR, Salinas PC (2000) Axonal remodeling and synaptic differentiation in the cerebellum is regulated by WNT-7a signaling. Cell 100:525-535. CrossRef Medline

Hu S, Begum AN, Jones MR, Oh MS, Beech WK, Beech BH, Yang F, Chen P, Ubeda OJ, Kim PC, Davies P, Ma Q, Cole GM, Frautschy SA (2009) GSK3 inhibitors show benefits in an Alzheimer's disease (AD) model of neurodegeneration but adverse effects in control animals. Neurobiol Dis 33:193-206. CrossRef Medline

Inestrosa NC, Arenas E (2010) Emerging roles of Wnts in the adult nervous system. Nat Rev Neurosci 11:77-86. CrossRef Medline

Killick R, Ribe EM, Al-Shawi R, Malik B, Hooper C, Fernandes C, Dobson R, Nolan PM, Lourdusamy A, Furney S, Lin K, Breen G, Wroe R, To AW, Leroy K, Causevic M, Usardi A, Robinson M, Noble W, Williamson R, et al. (2012) Clusterin regulates beta-amyloid toxicity via Dickkopf-1-driven induction of the wnt-PCP-JNK pathway. Mol Psychiatry. Advance online publication. Retrieved January 28, 2013. doi:10.1038/mp.2012.163. CrossRef Medline

Lie DC, Colamarino SA, Song HJ, Désiré L, Mira H, Consiglio A, Lein ES, Jessberger S, Lansford H, Dearie AR, Gage FH (2005) Wnt signalling regulates adult hippocampal neurogenesis. Nature 437:1370-1375. CrossRef Medline

Liu C, Li Y, Semenov M, Han C, Baeg GH, Tan Y, Zhang Z, Lin X, He X (2002) Control of beta-catenin phosphorylation/degradation by a dualkinase mechanism. Cell 108:837-847. CrossRef Medline

Maguschak KA, Ressler KJ (2008) Beta-catenin is required for memory consolidation. Nat Neurosci 11:1319-1326. CrossRef Medline

Maguschak KA, Ressler KJ (2011) Wnt signaling in amygdala-dependent learning and memory. J Neurosci 31:13057-13067. CrossRef Medline

Murase S, Mosser E, Schuman EM (2002) Depolarization drives betaCatenin into neuronal spines promoting changes in synaptic structure and function. Neuron 35:91-105. CrossRef Medline

Park M, Shen K (2012) WNTs in synapse formation and neuronal circuitry. EMBO J 31:2697-2704. CrossRef Medline

Purro SA, Dickins EM, Salinas PC (2012) The secreted Wnt antagonist Dickkopf- 1 is required for amyloid beta-mediated synaptic loss. J Neurosci 32:3492-3498. CrossRef Medline

Qin X, Zhang H, Zhou X, Wang C, Zhang H, Zhang X, Ye L (2007) Proliferation and migration mediated by Dkk-1/Wnt/beta-catenin cascade in a model of hepatocellular carcinoma cells. Transl Res 150:281-294. Medline

Qu Q, Sun G, Murai K, Ye P, Li W, Asuelime G, Cheung K, Shi Y (2013) Wnt7a regulates multiple steps of neurogenesis. Mol Cell Bio DOI 10.1128/MCB. 00325-13.

Rai M, Walthall JM, Hu J, Hatzopoulos AK (2012) Continuous antagonism by Dkk1 counter activates canonical Wnt signaling and promotes cardiomyocyte differentiation of embryonic stem cells. Stem Cells Dev 21:54-66. CrossRef Medline

Remage-Healey L, Maidment NT, Schlinger BA (2008) Forebrain steroid levels fluctuate rapidly during social interactions. Nat Neurosci 11:1327-1334. CrossRef Medline

Sadot E, Conacci-Sorrell M, Zhurinsky J, Shnizer D, Lando Z, Zharhary D, Kam Z, Ben-Ze'ev A, Geiger B (2002) Regulation of S33/S37 phosphorylated beta-catenin in normal and transformed cells. J Cell Sci 115:2771-2780. Medline

Sahores M, Gibb A, Salinas PC (2010) Frizzled-5, a receptor for the synaptic organizer Wnt7a, regulates activity-mediated synaptogenesis. Development 137:2215-2225. CrossRef Medline

Salcedo-Tello P, Ortiz-Matamoros A, Arias C (2011) GSK3 Function in the brain during development, neuronal plasticity, and neurodegeneration. Int J Alzheimers Dis 2011:189728. CrossRef Medline

Salinas PC, Zou Y (2008) Wnt signaling in neural circuit assembly. Annu Rev Neurosci 31:339-358. CrossRef Medline

Seib DR, Corsini NS, Ellwanger K, Plaas C, Mateos A, Pitzer C, Niehrs C, Celikel T, Martin-Villalba A (2013) Loss of Dickkopf-1 restores neurogenesis in old age and counteracts cognitive decline. Cell Stem Cell 12:204-214. CrossRef Medline

Shtutman M, Zhurinsky J, Simcha I, Albanese C, D'Amico M, Pestell R, Ben-Ze'ev A (1999) The cyclin D1 gene is a target of the beta-catenin/ LEF-1 pathway. Proc Natl Acad Sci U S A 96:5522-5527. CrossRef Medline

Spinsanti P, De Vita T, Caruso A, Melchiorri D, Misasi R, Caricasole A, Nicoletti F (2008) Differential activation of the calcium/protein kinase C and the canonical beta-catenin pathway by Wntl and Wnt7a produces opposite effects on cell proliferation in PC12 cells. J Neurochem 104:1588-1598. CrossRef Medline

Tabatadze N, Tomas C, McGonigal R, Lin B, Schook A, Routtenberg A (2012) Wnt transmembrane signaling and long-term spatial memory. Hippocampus 22:1228-1241. CrossRef Medline

Varela-Nallar L, Alfaro IE, Serrano FG, Parodi J, Inestrosa NC (2010) Wingless-type family member $5 \mathrm{~A}$ (Wnt-5a) stimulates synaptic differentiation and function of glutamatergic synapses. Proc Natl Acad Sci U S A 107:21164-21169. CrossRef Medline

Wey A, Knoepfler PS (2010) c-myc and N-myc promote active stem cell metabolism and cycling as architects of the developing brain. Oncotarget 1:120-130. Medline

Wey A, Martínez Cerdeno V, Pleasure D, Knoepfler PS (2010) c-and N-myc regulate neural precursor cell fate, cell cycle, and metabolism to direct cerebellar development. Cerebellum 9:537-547. CrossRef Medline

Wharton KA Jr (2003) Runnin' with the Dvl: proteins that associate with Dsh/Dvl 
and their significance to Wnt signal transduction. Dev Biol 253:1-17. CrossRef Medline

Yamada M, Ohnishi J, Ohkawara B, Iemura S, Satoh K, Hyodo-Miura J, Kawachi K, Natsume T, Shibuya H (2006) NARF, an nemo-like kinase (NLK)-associated ring finger protein regulates the ubiquitylation and degradation of T cell factor/lymphoid enhancer factor (TCF/LEF). J Biol Chem 281:20749-20760. CrossRef Medline
Zhang L, Yang X, Yang S, Zhang J (2011) The Wnt /beta-catenin signaling pathway in the adult neurogenesis. Eur J Neurosci 33:1-8. CrossRef Medline

Zhao Z, Fan L, Fortress AM, Boulware MI, Frick KM (2012) Hippocampal histone acetylation regulates object recognition and the estradiol-induced enhancement of object recognition. J Neurosci 32:2344-2351. CrossRef Medline 